\title{
Feasibility of Different Drying Methods to Remedy Deep-sea Mining Tailings Using the Formation of Alginate-rhamnolipid Complexes With Harmful Heavy Metals Contained in Manganese Nodules
}

\author{
Aleum Lee \\ Seoul National University \\ KYOUNGREN KIM ( $\sim$ kyoungrean@kiost.ac.kr) \\ Korea Institute of Ocean Science and Technology (KIOST)/University of Science and Technology (UST), \\ 385, Haeyang-ro, Yeongdo-gu, Busan 49111, Republic of Korea,
}

Keywords:

Posted Date: September 4th, 2020

DOI: https://doi.org/10.21203/rs.3.rs-56878/v1

License: (c) (1) This work is licensed under a Creative Commons Attribution 4.0 International License. Read Full License 


\section{Abstract}

The authors have requested that this preprint be removed from Research Square. 